\title{
AFRICAN METAPHYSICS AND RELIGIOUS ETHICS
}

DOI: https://dx.doi.org/10.4314/ft.v7i3.3

\section{Submission: January 20, 2018 Acceptance: November 6, 2018}

\author{
Motsamai MOLEFE, Ph.D \\ Department of Philosophy, University of the Witwatersrand \\ Email: motsaik@yahoo.com
}

\begin{abstract}
Scholars of African moral thought reject the possibility of an African religious ethics by invoking at least three major reasons. The first objection to 'ethical supernaturalism, ${ }^{1}$ argues that it is part of those aspects of African culture that are 'anachronistic' insofar as they are superstitious rather than rational; as such, they should be jettisoned. The second objection points out that ethical supernaturalism is incompatible with the utilitarian approach to religion that typically characterises some African peoples' orientation to it. ${ }^{2}$ The last objection argues that religious ethics by their very nature require the feature (of revelation), which is generally lacking in African religious experiences. The facet of revelation is crucial for a religious ethics since it solves the epistemological problem of knowing the will of God or the content of morality. In this article, I construct a vitality-based African religious moral theory; and, I argue that it can successfully meet these objections. Keywords: Ethical naturalism, Ethical supernaturalism, Humanism, Metaphysics, Religious ethics, Vitality.
\end{abstract}

\section{Introduction}

The postulation that religion plays a foundational role in ethics is common in African moral thought ${ }^{3}$ (see, MBITI 1971; MAGESA 1997; BUJO 2001; SHUTTE

\footnotetext{
1 'Ethical supernaturalism' is the claim that morality is essentially spiritual or religious. I use the notion of 'religion' and 'spirituality' interchangeably, not so much to refer to some institution or liturgy, but to pick out a particular kind of property, one that can be traced and identified with some divine entity.

${ }^{2}$ A 'utilitarian' approach to religion is the claim that African peoples are committed to some gods insofar as they can best deliver certain material benefits or consequences, otherwise such gods are jettisoned. By implication welfare is the chief good since any god can be evaluated against it.

${ }^{3}$ By 'religion' I am simply making reference to a particular kind of a property - a divine/spiritual property, not necessarily an organized institution of worship.
} 
2001). For example, John Mbiti (1975 175) states - 'It is believed in many African societies that their morals were given to them by God from the very beginning. This provides an unchallenged authority from the very beginning". Many scholars of African religious thought, however, tend to be vague regarding crucial details that ought to be a feature of a robust moral theory. Firstly, in terms of method, much of the literature tends to be overly anthropological insofar as they do not seek to systematically defend some moral claim largely on the basis of its rational appeal or some argument. ${ }^{4}$ For example, an influential theologian specializing in African religious ethics, Benezet Bujo (2001 10) states:

Black African rationality is much more inclusive. In the process of establishing norms for ethical-moral conduct, it includes things the contribution of that which cannot be justified in terms of reason alone.

The limitation of such a largely non-discursive approach to ethics is that it never yields an 'ethical theory' in a true sense of the term, which essentially implies a systematic rational reflections on (African) moral beliefs and their defense on the basis of reasons that either weigh on their support or weigh against their support, thus either demonstrating their plausibility or implausibility ${ }^{5}$ (POJMAN 2002; GYEKYE 2010). Taking such a largely non-discursive approach usually ends up with something like moral anthropology or descriptive ethics, which does no more than merely inform us of African peoples' actual moral beliefs. The idea of ethics requires the element of rational justification.

\footnotetext{
${ }^{4}$ The four books that exemplify this concern: Laurenti Magesa (1997) African Religion: The Moral Traditions of Abundant Life; Benezet Bujo's (1998 \& 2001); The ethical Dimension of Community: The African Model and Dialogue Between North and South \& Foundations of an African Ethic: Beyond the Universal Claims of Western Morality; Augustine Shutte (2001) Ubuntu: An Ethic for a New South Africa. Much of these discussions take a shape of moral anthropology rather than moral philosophy. In the latter, the focus is on justifying principles on the basis of rationality (POJMAN 2002: 3). Furthermore, discussions in these books flip-flop between normative and descriptive accounts of morality and the work on the former is less than systematic and argumentative. Lastly, the notions of 'morality' and 'ethics' are used without clarity and precision. I say this because when one is presenting a 'moral' theory they could mean one of three things. Firstly, by 'ethics' one can mean a theory of right action - specify a ground norm by appeal to which one can distinguish what all right and wrong actions have in common (for example, see METZ 2007: 321). Secondly, by 'ethics' one can also be answering the question 'what makes a life to go best?' (PARFIT 2002: 134 - 140). Lastly, one could mean a theory of perfection, that is, 'what is a good person?' (MENKITI 2004, 324 - 326). But these kinds of distinctions and clarity are generally absent in the literature

${ }^{5}$ For informative elucidation on such non-discursive approaches see (Louw 2004).
} 
On my part, I set myself the task of constructing an African religious ethics. To do so, I will appeal largely to the techniques of analytic philosophy. Analytic philosophy privileges conceptual analysis and argumentation to ground a moral theory that is not only African, draws from moral intuitions prevalent below the Sahara, but also plausible since it will be based largely on rational considerations that weigh on its favor.

For the sake of argument, I will stipulate or take for granted the truth of the metaphysical system that will ground the religious ethics proposed in this article. In other words, it is not within the scope of this article to theoretically justify certain metaphysical features grounding the religious ethics to be articulated here. My aim is not so much to justify these metaphysical considerations themselves - I take these for granted; but, mainly, the focus of my argument is to demonstrate that if they are true then they can ground a robust African religious ethics.

Secondly, some African scholars tend to be unclear with regards to what exactly they have in mind when they talk about ethics. The notion of ethics is generally used without clarity and precision. I say so because talk of a moral theory/ethics can mean several distinct things (see, KORSGAARD 1983; PARFIT 2002; METZ 2007; MOLEFE 2015a). I respond to this deficiency in the literature by philosophically reconstructing an African religious moral theory, which invokes the ontological property of vitality. I do so, informed by some assumptions regarding what constitutes a religious ethics i.e. the idea that:

... religious ethics presuppose a certain conception of human decision and imply that moral theory, including the study of comparative religious ethics, is incomplete without metaphysics, that is, critical reflection on the character of reality and human purpose as such (GAMWELL 2005, 112, emphasis mine).

Taking the idea that 'morality is incomplete without metaphysics', I construct an African religious ethics that is essentially grounded on a vitalist metaphysics (ontology) since the notion of vitality - or simply, life - is understood to encapsulate the very fundamental character of African ontological thought (TEMPELS 1959; MAGESA 1997; BUJO 2001; SHUTTE 2001; MOLEFE 2015b). By 'religious ethics', I am referring to a meta-ethical theory i.e., an account of the nature of moral properties that they are spiritual, given the supernatural ontology (character of reality) that informs African thought (GYEKYE 2010; MOLEFE 2013). By 'supernatural', I mean, moral properties are 
spiritual and as such cannot be accessed by appeal to scientific methods. ${ }^{6}$ I wish to construct a Vitality-based meta-ethical theory with the intention to ultimately demonstrate that it can successfully refute the criticisms alluded to above.

I structure this article as follows. I first discuss and define the notion of vitality and related terms like 'life' or 'life-force' in the context of an African ontology. This I do for the sake of an audience that may not be familiar with African thought and its cosmology. Secondly, I discuss the meta-ethical view that flows from the notion of vitality. Thirdly, I contrast this theory with the Divine Command Theory (DCT) for the sake of demonstrating the philosophical robustness (if not plausibility) promised by this under-explored African religious moral theory. I conclude the article by offering responses to the three criticisms offered against ethical supernaturalism in the African tradition.

\section{Vitality and its Ontology}

In introducing an African ontology that informs a talk of vitality, I clarify one issue. I caution the reader that it is true that African intellectual cultures are characterized by dynamism and marked diversity across time and space. It would be a disservice to speak of 'African' reality as if it is monolithic, static and homogenous (Louw, 2004). However, noting these glaring differences among the peoples of Africa does not in and of itself negate an observation made by many African scholars that there are overlapping commonalities and continuities among African peoples, which might justify what we may call an African metaphysical view (RAMOSE 1999; EZE 2005). My discussion of an African metaphysical system will draw on these common themes that attempt to capture in broad and general terms considerations that inform, among others, the notion of vitality, which in turn grounds a life-based ethics envisaged here ${ }^{7}$.

\section{An African Ontology}

I understand one salient interpretation of an African system of reality to be generally characterized by a trilogy of features, namely: supernaturalism, holism and vitality (MOLEFE 2015a). I here stretch the notion of 'supernaturalism' to represent a cosmology that embraces the physical as well the spiritual things as components of one world (GBADEGESIN 2005, 415-416). By 'physical', roughly,

\footnotetext{
${ }^{6}$ It is not within the scope of this article to solve epistemological questions about how to access these moral properties.

${ }^{7}$ My aim is not to defend this African metaphysical worldview
} 
I mean stuff we can investigate by appeal to some empirical recourse. On the other hand, 'spiritual' refers to stuff that is beyond any empirical recourse like God and ancestors. Typically, Africans are committed to a cosmology that comprises physical and spiritual things (GYEKYE 2010). Thus, one can safely observe that a dominant interpretation of African tradition espouses an ontology that goes beyond the empirical. The belief in this metaphysical system is that all reality is housed in the 'world'; as such, there is no talk of between heaven and hell and so on (OKEJA 2013, 112]

Secondly, the African understanding of reality is typically construed as holistic. 'Holism' is a view that construes all reality as interrelated and interdependent. With regards to holistic thinking, Bujo observes that "Africans do not think in 'either/or', but rather in 'both/and' categories" (BUJO, 2001, 3). Heidi Verhoef, an American scholar, observes that in the African tradition "Everything God, ancestors, humans, animals, plants and inanimate objects - is connected, interdependent and interrelated" (VERHOEF and MICHEL 1997, 395). On this ontological system, reality is understood essentially in relational terms: things live and thrive only in relationships. I believe that this idea of holism shares a lot in common with the idea of ibuanyindanda [Asouzu 2016]. I leave it for a future project to explore the details of these metaphysical concepts or system.

In light of this holistic conception of reality, the high prize usually given to the community should come as no surprise (MBIGI 2005, 75). One interesting way of thinking about the world (holism) in this system of thought is in terms of a hierarchy. As Laurenti Magesa $(1997,39)$ states:

In the conception of African religion, the universe is a composite of divine, spirit, human, animate and inanimate elements, hierarchically perceived, but directly related, and always interacting with one another.

In this hierarchy, God occupies the highest position, followed by ancestors, human beings, animals, animate objects and, at the bottom, inanimate ones. The crucial question to ask then is: how do we explain this hierarchy? Or, what informs this hierarchy?

The standard answer within this metaphysical system is the notion of vitality. The idea of Vitality is pivotal in the African metaphysical system. So much so that some African scholars claim that "The concept of energy or vital force is central in African ontology" (BIKOPO \& VAN BOGAERT 2009, 42). 'Vitality' refers to a spiritual energy that is originally and essentially a feature of God since it maximally inheres in him; and God has since distributed it to everything in the world (BIKOPO \& VAN BOGAERT 2009: 44). There is no 
reality that does not possess this spiritual energy, albeit in varying degrees. The supernatural realm possesses highest levels of life force; the human possesses more vital force than than animals do and so on (IMAFIDON 2013). The notion of 'vitality' as used here differs from how it is understood in the Western tradition, which typically tends to think of it in terms of the idea of a soul (for such Western accounts see METZ 2012: $24 /^{8}$ ). Vitality is considered as a sacred gift, a spiritual energy and an offshoot of God that characterizes every object. On the other hand, the possession of a soul tends to be a feature that is reserved only for human beings. With this sketchy view of an African ontology, we can turn now to discuss a Vitality-based meta-ethical theory derived from it.

\section{Meta-ethics of Vitality}

Influential African philosophers like Wiredu and Gyekye, among others, argue that for African ethics to be religious it requires, as a matter of necessity, to be grounded on revelation or some form of institutional religion like Christianity (WIREDU 1992; GYEKYE 1995). They also observe African religion tends to lack the general feature of being revealed or institutionalized; hence, African ethics cannot (ought not) to be considered religious. It is true that African religion is not 'revealed', at least, not in the way revelation is typically understood within the Christian tradition. Revelation, within the Christian model that Wiredu is appealing to, serves an important epistemological function of revealing the will of God through the means of scriptures, the Decalogue and so on. This revelation model is compatible with the dominant Western meta-ethical theory-the Divine Command Theory (DCT)-that defines 'rightness' and 'wrongness' relative to God's commands (JOYCE 2012, 49). The relevant religious institution(s) become a place for revealing the will of God.

Elsewhere, I have offered an extensive criticism of this argument by Wiredu and Gyekye (MOLEFE 2013). I observe, however, that an African moral system proffered here offers an interesting meta-ethical system that entirely relies on the notion of vitality, a divine property. Within this framework, vitality is considered to be the foundational or intrinsic moral property that is crucial for making sense of a morally sound life For example, Placide Temples (1956, 44-45), who may be considered a pioneer of African philosophy observes that:

8 Gunnar Stollberg offers a comprehensive understanding of vitalism from a Western tradition. He distinguishes between three understandings of vitality, historically: vitality as 'forming power', 'anima that brings matter to life' or 'as an organizing power' (no date). 
The Bantu say in respect of a number of strange practices in which we see neither rhyme nor reason, that their purpose is to acquire life, strength or vital force to live strongly, that they are to make life stronger, or to assure that force shall remain perpetually in one's posterity. Used negatively, the same idea is expressed when the Bantu say: we act thus to be protected from misfortune, or from a diminution of life or of being, or in order to protect ourselves from those influences which annihilate or diminish us.

In this light, Pantaleon Iroegbu (2005, 448), an expert in African ethics, also observes that:

This brings to focus the positive value of life because it is divine in resemblance, it must be taken loftly and with highest respect. It must be seen for what it is: of high value.

Godfrey Onah also observes:

At the centre of traditional African morality is human life. Africans have a sacred reverence for life.... To protect and nurture their lives, all human beings are inserted within a given community.... The promotion of life is therefore the determinant principle of African traditional morality and this promotion is guaranteed only in the community. Living harmoniously within a community is therefore a moral obligation ordained by God for the promotion of life. (ONAH 2013)

Laurenti Magesa an expert on African theological ethics states,"For the African, life is the primary category for self-understanding and provides a framework for any interpretation of the world, nature, or divinity" (cited in MAGESA 1997, 71).

From the above quotations, it is unequivocal that life is considered to be a fundamental moral norm or good. Taking life to be so basic amounts to the view that the whole enterprise of morality revolves around the single superlative value of life, and other values are derivatively good, if at all. Morality in a crucial way consists in how we treat or relate to the basic value of life. To properly appreciate the high prize attached to life in the African context, it is urgent that we construe it in light of the universal problem of death. An African understands her experience in the world in terms of a war between life and death. In this light, Bujo (2008, 282) states: 
Africans believe life to be most sacred but life is permanently threatened by death. The human person's task is to identify the enemies of life to defeat death.

So, the greatest good is life or life enhancing activities and morality requires that we befriend it. Death enhancing activities are considered to be the greatest evil and morality requires that we distance ourselves from such activities. It is also crucial that we understand that usually, African scholars tend to talk about death in two related ways ${ }^{9}$. Africans talk about death both in terms of a process and/or in absolute terms. Immediately the agent enters into a downward spiral wherein she is gradually losing her life force, what was referred to above by Tempels as 'diminishing of life force', then one has entered into a process of death; or, when one's loss of vitality becomes total i.e., they lose all their vital force, what was referred to above by Tempels as 'annihilation of vital force', then one has experienced absolute death ${ }^{10}$.

We start to realize that morality is ultimately about increasing and/or decreasing of vitality. At the heart of the African vitality meta-ethical theory is the question of how to positively relate to life and evade death (vitality consuming activities). The essence of the good is encapsulated by relating positively to life; and, the greatest evil is a matter of relating negatively to life. So, we can define the property 'right' and 'wrong' as a matter of either relating positively or negatively to life, respectively. A 'positive' relation to vitality refers to a situation wherein one preserves and nurtures her vitality; and, a 'negative' relation to vitality refers to a situation where one fails to keep and nurture her vitality and thus slips into a

\footnotetext{
${ }^{9} \mathrm{I}$ am aware that this view may raise issues about death and its relation to the transition to being an ancestor. The idea of 'death' under consideration is a moral one in some sense - I am here having in mind the death that comes about as the agent through moral pollution eats away their vitality.

${ }^{10}$ One may here raise scruples of consistency with regard to the claim of the all-pervasiveness of vital force and the possibility of a total loss of vital force. It is not within the scope of this paper to respond to some of these metaphysical concerns. It suffices, however, to observe that human agency, on this system of reality, can form an alliance with the enemies of life to a point of total loss of vital force. It is safe then to assume that the depleted vital force returns to God since it originally comes from him. For example, commenting in a bioethical context Van Bogaert et al comments thus about death - "Death has two degrees: one may be dead or completely dead. Bantus distinguish in humans the body, the shadow, and the breath. Breath indicates life; it cannot subsist after death. What subsists after death is the 'self' that was hidden behind the body during life. The process of dying is not static; it goes through progressive stages of energy loss. To be dead means to have a diminished life because of a reduced level of energy. When the level of energy falls to zero, one is completely dead" (2009 46).
} 
process of death. Thus, to invoke the property 'right' is to assert a positive relation to life; and, 'wrong' to assert a negative one.

So, we come to a meta-ethical theory of vitality that defines the property 'right' in terms of more life; and 'wrong' in terms of diminishing of life. If this meta-ethics of vitality of life that defines rightness in terms of 'positive relation to vitality' and wrongness in terms of 'negative relation to life' is correct, then it is a telling response to the objection that a religious ethics necessarily requires revelation. On this view, morality does not require any such institutions or even revelation. All that is required is for the agent to be cognizant of friends of life that lead to its enhancement and enemies of it that tend towards death. Such a psychological make-up is pervasive among African cultures that accentuate respect for life ${ }^{11}$.

This understanding of God as essentially characterized by vitality has interesting implications for theology and morality ${ }^{12}$. It presents a fresh perspective to religious ethical systems. Typical systems conceive of God as an (all) powerful, knowing and loving. This African ontological system conceives of God as chiefly characterised by life, and the cosmos that he created partakes and is also characterised by this life force.

To further clarify the vitalist meta-ethical account, I now give a rough comparison of it against the dominant religious meta-ethical account in the Western moral tradition (DCT). Jonathan Berg $(1991,525)$ distinguishes between two versions of the DCT: the linguistic and Extensional interpretations. The extensional view is generally considered to be plausible, I follow this intuition ${ }^{13}$. An 'extensional' view simply argues that the idea of 'God's will' and 'the good' are co-referential terms. In other words, the idea of 'God's will' and that of 'the good' do not mean the same thing "but amount to the same thing - that is, God wills whatever is good, and whatever God will's is good" (BERG 1991, 526, see also HARRISON 1978, 582). To clarify this relation of extensionality, the idea of 'a man who was in prison for 27 years, fighting for the liberation of South

\footnotetext{
${ }^{11}$ One may 'realise' that they have life by means of an intuition, which is best guided or informed by the tension between life and death that characterises life's journey. One may know by the guidance of the elders and/or ancestors.

${ }^{12}$ I will not explore the theological implications here since I am interested only in constructing an ethical theory.

${ }^{13}$ Berg comments thus on the linguistic version - "the idea (is that) ... God's will and the good ... are one and the same thing, that to be morally good just is, by definition, to be as God wills" (BERG 1991, 525, see also HARISSON 1978, 582, 583 - 584). In other words, to say that something is good is semantically equivalent to saying it is commanded by God or is God's will. This version is generally considered implausible, I will not consider it here (BERG 1991).
} 
Africans' and that of 'the first Black president in South Africa' do not mean the same thing but amount to the same thing (person) - Nelson Mandela.

Supposing the extensional view (of DCT) is true then it follows that 'rightness' is a function of what God commands and 'wrongness' of what he forbids. In this light, morality according to DCT is strictly about obeying God's command. In the African tradition, however, morality is about a positive or negative relation to a divine energy of life. Morality is entirely defined by appeal to a spiritual property of life and is geared to the promotion or honoring or perfecting of life depending on the posture of one's moral theory ${ }^{14}$. According to DCT, when you say something is right you simply mean that it is commanded by God; and, according to an African theory you mean it has a positive relation to life, a property of God.

Can the life-based moral theory overcome some of the weaknesses of DCT? DCT is usually objected to by appeal to the 'Euthyphro problem' because it defines rightness in terms of God's command. The Euthyphro problem has two horns. It is either something is good simply because God loves it - this renders morality arbitrary - or God loves it because it is loveable - this renders morality independent of God since he would have appealed to an independent property to evaluate that some property is worth being loved (BERG 1991, 547). This objection sticks because DCT identifies (defines) 'the right' in terms of God's command. The charge typically is that it makes morality arbitrary because God can command cruel actions (think about Abraham's example in the Old Testament) or one is stuck with the idea of morality being independent of God.

On the face of it, the Euthyphro problem does not appear to affect a vitality-based meta-ethical theory because it locates morality in the property of God, life; rather than specifically on his commands. The vitalist moral theory interprets God's will in terms of issues revolving around life and death. On this view, God does not have to say or write anything, as in the Bible or send some prophet or some institution like a church - though he may do so. Morality is a function entirely of how we interact with vitality; positive interaction constitutes rightness and the negative one wrongness. The central moral notion of vitality

\footnotetext{
${ }^{14}$ By 'posture', here, I am indicating that the positive relation at heart will be shaped by whether one takes a consequentialist that requires an agent to promote life; a deontological approach that requires an agent to respect/honor life (McNAUGHTON and PARIS 1992) and perfectionism requires an agent to perfect life (METZ 2007). Though, I think the last best captures African moral thought, it is however outside of the scope of this paper to concern myself with such normative theorisation issues.
} 
offers an interpretative or evaluative framework for determining rightness or wrongness of actions or, what is to count as generally accepted human conduct.

Another difficulty associated with DCT is that even if we accept that it is true, we still have to worry about which religion truly reveals the will of God - a question that is far from simple. On the other hand, the African religious ethics, locates morality on something intrinsic to every human being - life. One does not have to go to any institution, prophet or God to understand that they have life, supposing that she is familiar with this metaphysical system that is basic in African cultures, where the major psychological orientation is identifying the 'enemies' (things that diminish vitality) the of life and appreciating the 'friends' (things enhance vitality) Another positive feature of this life principle is that though it is spiritual, it can be seen in concrete terms in this fashion:

... they say that a human being is special in virtue of being able to exhibit a superlative degree of health, strength, growth, reproduction, creativity, vibrancy, activity, self-motion, courage and confidence, with a lack of life force being constituted by the presence of disease, weakness, decay, barrenness, destruction, lethargy, passivity, submission, insecurity and depression. (METZ 2012: 25) ${ }^{15}$

So, we can assess more life in terms of these physical manifestations like strength, health, reproduction, among others; and, we can equally see the loss of life through these physical manifestations. A possession of healthy contents of life is evidenced by positive physical manifestation. Thus, this religious ethics can appeal to these so-called physical manifestations of more life insofar as they reflect the quality of the condition of one's vitality to judge whether an act is right or wrong, unlike DCT which has to appeal merely to what God commands, which at times does not cohere with common sense morality like the case of Abraham in the Bible, wherein he is required to kill his son.

Above, I gave two reasons why we should consider the vitality based moral theory robust given that (1) it appears to do better than DCT in terms of the Euthyphro problems and (2) it makes morality less mysterious by offering some physical evidence about why some actions are right and some are wrong. ${ }^{16} \mathrm{I}$

\footnotetext{
${ }^{15} \mathrm{I}$ am aware that Metz is a naturalist and he construes a vitalist meta-ethics strictly in physical terms. In this project, in keeping with a common interpretation literature, I take vitality to be a spiritual term. I take the physical manifestations to be supervenient on the spiritual; as such, they are good indicators of instances of more life or loss of life.

${ }^{16}$ For a detailed comparison between the vitality-based religious ethics and the DCT (see, MOLEFE 2017)
} 
proceed now to respond to criticisms against a possibility of an African religious ethics that I alluded to in the introduction.

\section{Response to Criticisms of Religious Ethics}

In the introduction, I mentioned three criticisms that are usually offered to support the view that African ethics cannot be religious. Firstly, there is the charge of anachronism by Wiredu to the effect that a talk of 'ethical supernaturalism' posits spiritual things born of superstition and speculation that reflects a lack of scientific development in African culture and as such should be jettisoned for a more robust scientific and humanistic culture. Secondly, it is the claim that African religion is utilitarian by nature i.e., it is central focus is maximising human welfare. This probably explains why gods that do not work towards the welfare of human beings under its care, tend to be jettisoned. Lastly, it is the argument that for any ethics to be religious it must be a revealed or institutional religion; and, African religion(s) are not revealed and therefore cannot house a religious ethics. Elsewhere, I have responded sufficiently to the criticism that the possibility of an African religious ethics requires revelation and institutionalized religion (MOLEFE 2013). In this article, I further suggested that revelation as imagined within the Christian model is not necessary in the African system ${ }^{17}$. In what follows, I will concern myself with the other two criticisms.

\section{Religious Properties and Anachronism}

The claim that spiritual entities are 'unscientific' cannot be disputed by anyone who understands terms under consideration. It is also a banality to point out that it is not always necessary to explain happenings in the world by appeal to spiritual beings (MASOLO 2010). It is true that reference to God, vitality, ancestors and so on appeals to things that are beyond the reach of scientific tools, which operate on the methodological basis of empirical experimentation. It is, however, not true that talk of such spiritual beings reflects mental and scientific under-development. Also, the fact that some claims that philosophers make are not scientific does not make them obviously false and unphilosophical in character.

For one to reasonably arrive at the conclusion that to make reference to spiritual things is anachronistic, one must prove philosophically that spiritual things do not exist otherwise it strikes me as 'biting too much' to claim that they

\footnotetext{
${ }^{17}$ Steven Bantu Biko (2004 47) gives an interesting insight about why African religion did not have institutions, books and buildings (a church). He observes that the whole of life, be it in agriculture, home, beer-drinking and performing some ritual was a deeply spiritual encounter because it was an opportunity to celebrate, exchange and grow life. Worship was not limited to some place or event; life in totality was a continuous context of engaging in the spirituality.
} 
are anachronistic. This is the case given that many people even in the so-called scientific societies still hold beliefs about such spiritual entities like God. They even proffer rational accounts for why we must take the existence of such beings seriously. I am aware that believing in spiritual entities does not entail their existence as much as not believing in them does not amount to their non-existence.

The charge of anachronism is problematic for several reasons, the major problem being an unjustified commitment to (ontological) materialism; the view that all that is real or exists is physical and nothing more. It is particularly difficult to defend this view ${ }^{18}$. This claim also finds expression in the African moral tradition: it is usually expressed in terms of 'ethical naturalism' - the claim that moral properties are best and only understandable in physical terms (WIREDU 1992; METZ 2007, 328). Typically, in the African tradition the relevant physical site for harvesting moral truths is some facet of human nature and this moral doctrine goes by the name of 'humanism' (WIREDU 1992; GYEKYE 1995; METZ 2007, 2009, 2012; MOLEFE 2015b). It is such a commitment to materialism-humanism that attempts to relegate supernatural properties in moral thought to a status of things that are anachronistic ${ }^{19}$.

The conclusion that all reference to spiritual things is anachronistic hides a more fundamental philosophical commitment to materialism, which itself begs for justification. It does not help the case of materialism that it is not justified in the philosophical works of these philosophers - it is either stipulated or taken for granted (WIREDU, 1992; GYEKYE, 1995; METZ, 2007). It is for this reason that much of my discussion about vitality, at least at this stage, it is also taken for granted. So, a positive challenge I take from this criticism of anachronism is that African philosophers have to develop arguments as to why talk of God, ancestors and things like vitality ought to be taken seriously on rational grounds. And that it is no longer enough to hold to claims like: "in truth, most Akans espouse that metaphysics as a matter of course. Akan conventional wisdom actually holds that the existence of God is so obvious that it does not need to be taught, even to a child" (WIREDU 1992, 194, see also BUJO 2001; GBADEGESIN 2005).

As a result, Africans and African philosophers have not seriously engaged in the project of philosophizing about these metaphysical aspects of our culture. One, for example, would not find arguments for the existence of God from an

\footnotetext{
${ }^{18}$ See the debate between Gyekye and Wiredu on whether the Okra is physical or spiritual. This debate is about whether human nature is entirely constituted by material or it has some spiritual features (See, Kaphagawani 2004) - he offers an illuminating summary of this debate between physicalists and dualists with regards to human nature.

${ }^{19} \mathrm{I}$ have refuted this theory in another place. I have attempted to demonstrate its implausibility [MOLEFE 2013; 2015b].
} 
African perspective other than mere pragmatism (GBADEGESIN 2005). I strongly suggest that a more positive move is one that will encourage serious philosophising about these spiritual entities from an African perspective and see what value may be gotten from such endeavors rather than carelessly classifying everything that does not meet the standards of a scientific and technological cultures as anachronistic. But this lack of philosophical defense of these entities does not lead necessarily to the idea that one cannot have a robust moral theory grounded on such properties whilst waiting for some defense of these properties in the future.

More positively, I take Wiredu not to be so much declaring the belief in God and such like entities to be philosophically implausible. What he considers anachronistic and in need of reformation is to base the entire African culture and its quest for development on supernatural basis. A robust culture will accommodate the benefits of the scientific culture in imagining itself and this will be balanced with certain African metaphysical and cultural facets that need not be necessarily opposed to science. The problem is not a belief in God or ancestors per se, but the role they may be imagined to play in a particular culture. As such, there is nothing in the proposed African religious ethics encouraging science to help us find effective ways to increase life and decrease death. This religious ethics, for example, will definitely be opposed to things like nuclear weapons, as these works of science threaten vitality.

\section{Religion and Utility}

The criticism here points out that morality cannot be founded on religious considerations because gods are subject to morality and in a way morality is not subject to them. If gods are subject to morality then this view implies that morality is independent of gods. Note this submission, for example:

[The] manifestation of religion on the African landscape is not an abstract idea. It is purposeful; it is utilitarian. In traditional Africa, humanity is not made for religion, religion is made for humanity ... the gods are subject to human evaluation and assessment. (GBADEGESIN 2005, 414)

What stands out here is the implication that there is an independent moral standard against which gods are assessed to the effect that gods themselves can fail at being moral if they do not match up to the standard of promoting human welfare. If this is the case then morality is prior, independent and even more normatively powerful than gods since it may be invoked to facilitate their rejection (WIREDU 1992).

It should be noted that the metaphysical system informing this objection is different from the one grounding the vitality-based moral theory. The telos 
informing the objection is utility or human welfare, which is typical in some interpretations of the Akan and Yoruba cultures (WIREDU 1992; GYEKYE 2004). I articulated a metaphysical system where God is subject to these kinds of utilitybased evaluations; and, more importantly, where morality depends on his divine property of vitality. In other words, in the vitality based moral scheme, God cannot be jettisoned for reasons involving utility. It is also important to note that the metaphysical system informing the objection takes a polytheistic approach, and the one I suggested takes a monotheistic orientation. Could it be that it is the gods (various lesser divinities) that can be jettisoned and not God (uMvelinqangi) that cannot be jettisoned. It appears that here we are talking about two different metaphysical systems and therefore moral systems informed by differing value systems: one grounded on welfare and the other on vitality - this observation appears to be sustained by Wiredu (1992).

In the Akan system in question, the earth is construed as laden with resources and potentialities that may benefit humanity if they appeal correctly to the divinities ('gods') and if these ('gods') fail to deliver the relevant and desired benefits, they may be jettisoned. Wiredu, however, is quick to distinguish these gods that may be jettisoned from "the Supreme being, which is one of unconditional reverence and absolute trust" (1992 195). So, the system of morality defended here is riveted on God and his vital force; and, God is essential in this moral scheme - it is impossible to abandon God, at least, in this system and still talk meaningfully about reality and morality.

So, whereas this criticism might apply to a welfare-based onto-ethical framework that posits some lesser divinities that have access to some benefits of the cosmos that may improve human welfare, it fails to apply to a life-based (Bantu culture-based) onto-ethical tradition, where God is understood as a permanent and sovereign feature of planet earth, where the highest good is promoting life (SHUTTE 2001).

So, above, I highlighted a religious ethics grounded on the metaphysical property of vitality. Rightness, on this meta-ethical view, is function of a positive relation to life, which is tantamount to preserving or increasing life; and, wrongness is a function of a diminution or loss of life. I responded to the three objections by noting. The requirement of revelation is rendered otiose if morality is based on the intrinsic property of vitality. On the vitality view of morality is about issues of life and death. So, there is no need for revelation. The objection of anachronism assumes less than it has proven with regards to spiritual properties. The mere fact that we have not demonstrated scientifically the existence of such spiritual beings, does not imply that they do not exist or that we cannot construct meaningful moral theories given that many of our people still believe in such 
things ${ }^{20}$. Lastly, the utilitarian objection will hold only to those who take the entire enterprise of morality to be founded on utility, a position I reject in favour of one grounded on life. On this reading of a religious ethics, God cannot be easily jettisoned for the sake of utility; if utility matters at all, it matters only derivatively or secondarily.

\section{Conclusion}

In this article, I articulated a vitality-based moral theory about what we might mean when we use ethical terms like 'right' and 'wrong'. I constructed a spiritual understanding of morality drawing from ontological resources prevalent among the Bantu cultures (among others) that posit vitality as a fundamental onto-ethical property. 'Rightness' is a function of preserving/promoting life; and, 'wrongness' of diminishing life. To reveal the philosophical robustness of this life-based metaethical view, I contrasted it against DCT, a dominant Christian meta-ethical theory. I concluded by responding to some criticisms against the possibility of a religious ethics in the African tradition. In the future, it might add to the corpus of this metaethical theory to explore what normative theory can be gleaned from it and whether its plausible version is one that takes a consequentialist, deontological or perfectionist interpretation.

\section{Relevant Literature}

1. ASOUZU, Innocent. "Fidelity to Western Metaphysics: A Challenge to Authentic African Existence," [Filosofia Theoretica], pp1-16, 2016. Vol 5. No 1. Web.

2. BIKOPO, Dembe. and VAN BOGAERT, Lange. "Reflection on Euthanasia: Western and African Ntomba Perspectives on the Death of a Chief," [Developing World Bioethics], pp42-48, 2009. Vol. 10. Web.

\footnotetext{
${ }^{20}$ The reviewer presses me to consider the force of this objection to be not so much the rejection of the supreme being, but to point out that the starting point ought to be the natural and progresses to the supernatural. The implication of such a view could be that the physical is primary, and the spiritual is secondary. In other words, on this view the foundations for morality is the human good and the religious consideration plays an instrumental role. This objection begs the question about the deep metaphysical view - how do we justify the physical over the supernatural? On my part, I work with a metaphysical system that locates God as the primary source of value, by linking morality with the metaphysical property of vitality. As such, the final philosophical contestation will not be at the level of morality, but at the metaphysical level physicalism versus supernaturalism.
} 
3. BUJO, Benezet. [The Ethical Dimension of Community: The African Model and the Dialogue between North and South], 1998. Pauline's Publications Africa: Nairobi. Paperback

4. BUJO, Benezet. [Foundations of an African Ethic: Beyond the Universal Claims of Western Morality], 2001. The Crossroad Publishing Company: New York. Paperback

5. DZOBO, Komla. "Values in a Changing Society: Man, Ancestors and God," [Person and Community: Ghanaian Philosophical Studies, 1, Kwasi WIREDU and Kwame GYEKYE Eds], pp 223 - 242, 1992. Council for Research in Values and Philosophy: Washington DC. Paperback

6. GAMWELL, Francis. "Norms, Values and Metaphysics," (The Blackwell Companion to Religious Ethics., William, Schweiker Ed.), pp112-120, 2005. Blackwell Publishing: Oxford. Hardcover

7. GBADEGESIN, Segun. "Origins of African Ethics," (The Blackwell Companion to Religious Ethics. William, Schweiker Ed.), pp413-423, 2005. Blackwell Publishing: Oxford. Hardcover.

8. GYEKYE, Kwame. "African Ethics." [The Stanford Encyclopedia of Philosophy, Edward ZALTA Ed.], N.P, January 2013. Web.

9. IROEGBU, Pantaleon. "Do All Persons Have a Right to Life?," (Kpim of Morality Ethics: General, Special and Professional., Pantaleon Iroegbu \& A. Echekwube Eds.), pp78-83, 2005. Heinamann Educational Books: Ibadan. Paperback

10. JOYCE, R. "Theistic Ethics and the Euthyphro Dilemma," [Journal of Religious Ethics], pp49-75, 2012. Vol. 30. Web.

11. KAPHAGAWAMI, Didier. "African Conceptions of a Person: A Critical Survey," (Companion to African Philosophy, Kwasi WIREDU Ed.), pp332442, 2004. Blackwell Publishing: Oxford. Hardcover.

12. LOUW, Dirk. [Ubuntu and the Challenges of Multiculturalism in postApartheid South Africa], 2004. Centre for Southern Africa: Utrecht. Paperback 
13. MAGESA, Laurenti. [African Religion: The Moral Traditions of Abundant Life], 1997. Orbis Books: New York.

14. MBIGI, L. [The Spirit of African Leadership], 2005. Knowers: Randburg. Paperback

15. MBITI, John. [African Religions and Philosophy], 1975. Heinemann Educational Books: London. Paperback

16. MACNAUGHTON, David., \& RAWLING, Paris. Honouring and Promoting Values [Ethics] Vol 102, 835 - 843, 1992. Web.

17. MENKITI, Ifeanyi. "On the Normative Conception of a Person," (Blackwell Companion to African Philosophy. Kwasi Wiredu Ed.), pp324-331, 2004. Blackwell Publishing: Oxford.Hardcover.

18. _. Thaddeus. "Toward an African Moral Theory," [The Journal of Political Philosophy], pp321-341, 2007. Vol 15. Web.

19. _. Thaddeus. "Human Dignity, Capital Punishment and an African Moral Theory: Toward a New Philosophy of Human Rights," [Journal of Human Rights], pp81-99. 2010. Vol 9. Web.

20. _ _ Thaddeus. "Developing African Political Philosophy: Moral-Theoretic Strategies," [Philosophia Africana], pp61-83, 2012. Vol 14. Web.

21. MOKGORO, Yvone. "Ubuntu and the Law in South Africa," [Potchefstroom Electronic Law Journal], pp1-11, 1998. Vol 1. Web.

22. MOLEFE, Motsamai. "A Rejection of Humanism in African Moral Tradition," [Theoria], pp59-77, 2015a. Vol 143. Web.

23. __ Motsamai. [Explorations in African Meta-Ethics: A Case for Supernaturalism], 2015b. University of Johannesburg: Johannesburg. Hardcover.

24. ___ Motsamai. "Critical Reflections on Gyekye's Humanism: Defending Supernaturalism," (Ontologized Ethics: New Essays in African Meta-ethics. Elvis Imafidon and John Bewaji Eds.), pp121=133, 2013. Lexington Books: New York. Hardcover. 
25. Motsamai. "An African Religious Ethics and the Euthyphro Problem," [Acta academica], pp22 - 38, 2017. Vol 49. Web.

26. MUROVE, Felix. "An African Commitment to Ecological Conservation: The Shona Concepts of Ukama and Ubuntu," [Mankind Quarterly],pp195-225, 2004. Vol 45. Web.

27. PARFIT, David. "What Makes Someone's Life Go Best?," (Ethical Theory: Classic and Contemporary Readings. Lious Pojman Ed.), pp134-140, 2002. Wadsworth: London. Paperback.

28. POJMAN, Lious. "What is Ethics?," (Ethical Theory: Classic and Contemporary Readings. Lious Pojman Ed.), pp1-7, 2002. Wadsworth: London. Paperback

29. RAMOSE, Mogobe. "Ecology through Ubuntu," (African Ethics: An Anthology of Comparative and Applied Ethics. Felix Murove Ed.), pp308314, 2009. University of Kwa-Zulu Natal Press: Pietermaritzburg. Paperback.

30. SHUTTE, A. [Ubuntu: An Ethic for a New South Africa], 2001. Cluster Publications: Pietermaritzburg.

31. STOLLENBERG, G."Vitalism and Vital Force in Life Sciences - The Demise and Life of a Scientific Conception," [http://www.unibielefeld.de/soz/pdf/Vitalism.pdf], N.P, N.D. October 2015.

32. WIREDU, Kwasi. [Philosophy and African Culture], 1980. Cambridge University Press: Cambridge. Paperback.

33. __ Kwasi. "Moral Foundations of an African Culture," (Person and Community: Ghanaian Philosophical Studies, 1, Kwasi WIREDU, Kwame GYEKYE Eds.), pp192-206, 1992. The Council for Research in Values and Philosophy: Washington DC. Paperback. 